\title{
熱蛍光素子を用いた円筒型アクリル樹脂減速材付き 中性子線量計の開発
}

\author{
小川喜弘，妹尾貴文 \\ 近畿大学理工学部情報学科 \\ 577-8502 大阪府東大阪市小若江 3-4-1 \\ 2005 年 3 月 8 日 受理
}

\begin{abstract}
シーベルトメータによる中性子線量率の直接的な読み取りと比べて，減速材中に挿入されたパッ シブ熱中性子検出器は，中速エネルギーや高速エネルギー中性子測定とともに，モニタリング期間 にわたる低レベル中性子線量率の長期集積線量測定の可能性を示している。ここでは, 直径 $10 \mathrm{~cm}$, 厚さ $0.5 \mathrm{~cm}$ の円板状アクリル樹脂板を $15 \mathrm{~cm}$ 重ね, その間 $0.5 \mathrm{~cm}$ 毎に熱中性子検出器として $\mathrm{CaSO}_{4}: \mathrm{Tm}+{ }^{6} \mathrm{LiF}$ 及び $\mathrm{CaSO}_{4}: \mathrm{Tm}+{ }^{7} \mathrm{LiF}$ からなる熱蛍光素子の対を挿入した簡易パッシブ中性 子線量計を作製し， ${ }^{252} \mathrm{Cf}$ や $\mathrm{Pu}-\mathrm{Be}$ 中性子源を用いたいろいろな減速中性子場でその中性子線量計 の性能並びに特徵について考察した。更に，その中性子線量計の $10^{-9} \mathrm{MeV}$ から $20 \mathrm{MeV}$ までの応 答関数を作成した。最後に，その中性子線量計の読み取り值から中性子エネルギースペクトルを推 定し，精度の良い中性子線量評価法を開発するとともにその適応性について検討した。

中性子線量計の読み取り值と作成した応答関数を用いてアジャストメントされた中性子エネルギ 一スペクトルは， ${ }^{252} \mathrm{Cf}$ 並びに $\mathrm{Pu}-\mathrm{Be}$ 中性子源の中性子エネルギースペクトルを精度良く再現した。 また，推定された中性子エネルギースペクトルにもとづき評価した中性子線量は，いろいろな減速 中性子場において, $1.06 \times 10^{-4}$ から $1.45 \times 10^{-4} \mathrm{~Gy} / \mathrm{Sv}$, 平均 $(1.26 \pm 0.14) \times 10^{-4} \mathrm{~Gy} / \mathrm{Sv}$ であり， シーベルトメータとほほ同じ中性子線量応答（中性子線量に対する ${ }^{60} \mathrm{Co} \gamma$ 線に等価な吸収線量）を 示した。その結果，今回開発した簡易パッシブ中性子線量計は，いろいろな放射線場における熱中 性子から数 $\mathrm{MeV}$ の範囲の中性子エネルギーに対する平常時中性子モニタリングのための有用な測 定器であることを示唆している。
\end{abstract}

Key Words:neutron dose, neutron energy spectrum, acrylic resin moderator, thermoluminescent detector, response function, adjustment, neutron monitoring, neutron dosimeter

\section{1. 緒言}

中性子線量を推定する上で中性子エネルギー スペクトルは，原子炉，中性子発生装置や核燃 料再処理プラントの放射線場における中性子モ ニタリングに際して非常に重要な要因である。 そのため，中性子エネルギースペクトル測定は， 特に，中速エネルギーと高速エネルギー領域に おいて，重要な問題であるが，この領域での測 定法はあまりなく，通常, ${ }^{3} \mathrm{He}$ カウンタなどの $1 / \mathrm{v}$ 検出器の周囲をいろいろな厚さの減速材で
取り囲み，中性子エネルギーを得る方法が開発 されてきた。しかし，この方法では，多数回の 複雑な測定が必要となり, 平常時の中性子モニ タリングには非効率的である。そこで，これら の施設において，中性子モニタとしていわゆる シーベルトメータ（レムカウンタ）が, 熱エネ ルギーから数 $\mathrm{MeV}$ の範囲における平常時モニ タリングにおいて，しばしば用いられている。 一方，シーベルトメータによる中性子線量率 の直接的な読み取りと比べて，減速材中に挿入 されたパッシブ $1 / \mathrm{v}$ 検出器は, 中速エネルギ 
一や高速エネルギー中性子測定とともに，モ二 タリング期間にわたる低レベル中性子線量率の 長期集積線量測定の利点を持っている。

熱蛍光素子 ${ }^{1-3)}, \mathrm{CR}-39$ のような固体飛跡検 出器 ${ }^{4) 5}$, 核分裂飛跡検出器 ${ }^{6)}$ や放射化箔 ${ }^{7)}$ 用 いたパッシブ中性子スペクトロメータは，いろ いろな人たちにより開発されてきた。平常時モ ニタリングにおける実際的な使用のために，そ のような中性子スペクトロメー夕は, 構造が簡 単で計測が容易であるだけでなく，得られた測 定值から中性子エネルギーに関する情報を与え るとともに優れた中性子線量応答を持っていな ければならない。

そこで，これらの点を克服し，簡便で安定し た測定器動作を得るために, Singh ら゙ににより 提案されたパッシブ中性子スペクトロメータを 改良した熱蛍光素子を用いた簡易パッシブ中性 子線量計を作製し，その中性子線量計の性能並 びに特徴についていろいろな中性子場で考察し だ)。更に，その中性子線量計の $10^{-9} \mathrm{MeV}$ か ら $20 \mathrm{MeV}$ までの応答関数を作成した。最後に, その中性子線量計の読み取り值から中性子エネ ルギースペクトルを推定し, 精度の良い中性子 線量評価方法を開発するとともにその適応性に ついて検討した。

\section{2. アクリル樹脂減速材付き简易中性子測定}

\section{器}

簡易パッシブ中性子線量計は, Singh らによ り開発されたパッシブ中性子スペクトロメータ を改良し，作製した。Fig. 1 に示すように，直 径 $10 \mathrm{~cm}$, 長さ $15 \mathrm{~cm}$ の円柱状の本体の周りを, 前面と後面を除いて, 厚さ $5 \mathrm{~cm}$ のパラフィン で取り囲んだものである。

本体は, 厚さ $5 \mathrm{~mm}$ の円板状のアクリル樹脂 板をならべ，その間に $5 \mathrm{~mm}$ 毎に中性子検出器 である熱蛍光素子（熱蛍光物質の粉末を直径 2 $\mathrm{mm}$ ，長さ $12 \mathrm{~mm}$ のガラス管に封入）を挿入 した簡単なものである。使用した中性子検出用 熱蛍光素子は, $\mathrm{CaSO}_{4}$ 系の熱蛍光材に中性子

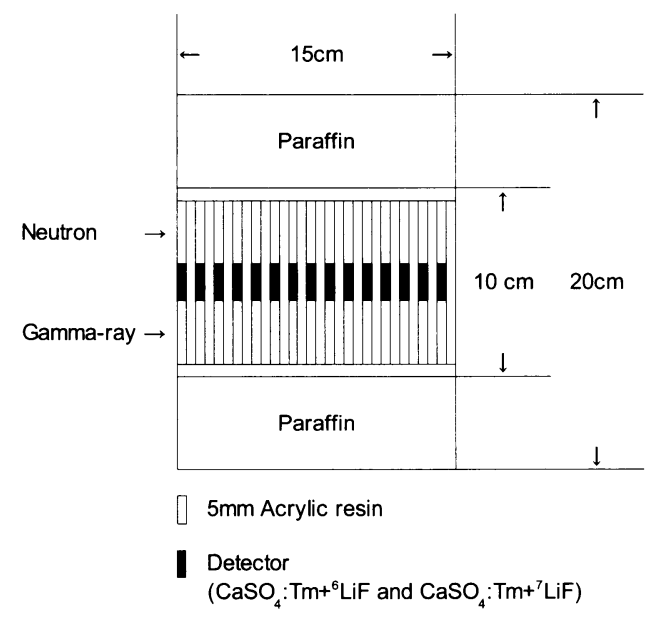

Fig. 1 Cross sectional view of the simple passive neutron dosimeter.

に感度を持たせるために ${ }^{6} \mathrm{LiF}$ を添加したもの (UD-136N, 松下電器製) と, ${ }^{7} \mathrm{LiF}$ を添加した $\gamma$ 線補償用熱蛍光素子 (UD-137N, 松下電器製) を対にして用い, 2 種類の熱蛍光素子の蛍光量 の差から中性子に関する熱蛍光量を求める。

種々なエネルギーの中性子は, 一方向 (前面) から入射し, 中性子線量計の各位置での熱蛍光 量の中性子に起因する熱蛍光量から入射中性子 の中性子エネルギースペクトルに関する情報並 びに中性子線量に関する情報を得る。

\section{3. 実臨}

中性子線量計の性能評価は, ${ }^{252} \mathrm{Cf}$ 並びに $\mathrm{Pu}^{-}$ $\mathrm{Be}$ 中性子源と異なった遮蔽材を組み合わせた いろいろな中性子場において行った。 ${ }^{252} \mathrm{Cf}$ 中性 子源は, 平均中性子エネルギーが $2.35 \mathrm{MeV}$ で あり, $2.2 \times 10^{3}$ neutrons/sec の中性子発生率で ある。また, $\mathrm{Pu}-\mathrm{Be}$ 中性子源は, 最大中性子 エネルギーが $10.6 \mathrm{MeV}$, 平均中性子エネルギ 一が3. $2 \mathrm{MeVであり,} 1.7 \times 10^{6}$ neutrons/sec の 中性子発生率である。Fig. 2 に使用した中性子 源の中性子エネルギースペクトルを示し ${ }^{9)}$, Table 1 に中性子線量計の特性試験を行った中性 子場をまとめる。

中性子源からの中性子と付随する $\gamma$ 線を中性 


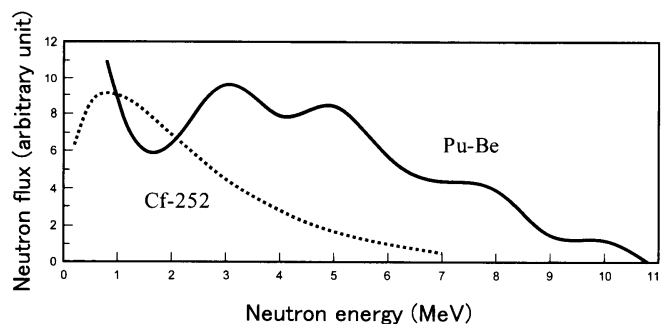

Fig. 2 Neutron energy spectra of ${ }^{252} \mathrm{Cf}$ and $\mathrm{Pu}-\mathrm{Be}$ neutron sources.

Table 1 Various neutron fields for measuring the performance of neutron dosimeter

\begin{tabular}{ccc}
\hline Neutron field & Neutron source & Shielding material \\
\hline I & ${ }^{252} \mathrm{Cf}$ & - \\
II & & - \\
III & & $1 \mathrm{~cm} \mathrm{Acrylic} \mathrm{resin}$ \\
IV & & $2 \mathrm{~cm}$ Acrylic resin \\
V & Pu-Be & $3 \mathrm{~cm} \mathrm{Acrylic} \mathrm{resin}$ \\
VI & & $5 \mathrm{~cm}$ Lead \\
VII & & $5 \mathrm{~cm}$ Paraffin \\
VIII & & $10 \mathrm{~cm}$ Graphite \\
\hline
\end{tabular}

子線量計の前面から数時間照射した後, $380{ }^{\circ} \mathrm{C}$ の温風加熱方式の熱蛍光読取装置（UD-502B, 松下電器製）を用いて, 各位置の熱蛍光素子の 熱蛍光量を測定した。その後, 中性子線量計の 中心軸に沿った中性子に起因する熱蛍光量の深 部分布を, $\gamma$ 線補償用の熱蛍光素子の熱蛍光量 を差し引きし評価した。そのような方法で測定 された中性子に起因する熱蛍光量は, ${ }^{60} \mathrm{Co} の \gamma$ 線に等価な吸収線量で校正した。同時に, 基準 測定器として Anderson-Brown 型 (AN-PDR-70 型, Tracerlab, USA）のシーベルトメータを 用いて中性子線量を測定した。

\section{4. 解 析}

\section{$4 \cdot 1$ 応答関数作成法}

この中性子線量計では, $10^{-9} \mathrm{MeV}$ から 20 $\mathrm{MeV}$ の中性子を測定対象とし, 応答関数は, 沉用 3 次元連続エネルギーモンテカルロシミュ レーションコード $\mathrm{MCNP}^{10)}$ を使用して決定し た。エネルギー分布は, $10^{-9} \mathrm{MeV}$ から $20 \mathrm{MeV}$
のエネルギー領域を ICRP Pub. 74「外部放射 線に対する放射線防護に用いるための換算係 数」 ${ }^{11}$ に対応した 47 群のエネルギー区分に分 割して評価した。

応答関数計算においては，各エネルギー区分 に対応するエネルギーの中性子をこの中性子線 量計の前面から垂直に入射させ， $1 \mathrm{~cm}$ 毎の各 位置の ${ }^{6} \mathrm{Li}(\mathrm{n}, \alpha)$ 反応率の深部分布を計算した。

\section{$4 \cdot 2$ 中性子エネルギースペクトル推定法}

一般に，エネルギー分布を持った中性子が中 性子線量計に入射した時, 中性子線量計の応答, すなわち, 各位置での熱蛍光量は, 応答行列を 用いると以下のようにあらわされる。

$\left(\begin{array}{c}T L_{1} \\ T L_{2} \\ \vdots \\ T L_{15}\end{array}\right)=\left(\begin{array}{cccc}R_{1,1} & R_{1,2} & \cdots & R_{1,47} \\ R_{2,1} & R_{2,2} & \cdots & R_{2,47} \\ \vdots & \vdots & \ddots & \vdots \\ R_{15,1} & R_{15,2} & \cdots & R_{15,47}\end{array}\right) \quad\left(\begin{array}{c}\phi_{1} \\ \phi_{2} \\ \vdots \\ \phi_{47}\end{array}\right)$

$$
T L=R \cdot \Phi
$$

ここで, $T L, R, \phi$ は，それぞれ，中性子線 量計の各位置での熱蛍光量, 応答行列, 中性子 エネルギースペクトルをあらわす。

したがって, 中性子線量計の応答行列が既知 とすると, 各位置での 15 個の測定された熱蛍 光量に応答行列の逆行列を乗じ, 47 群の中性 子エネルギースペクトルを推定することができ る。

$$
\Phi=R^{-1} \cdot T L
$$

このような手法で入射中性子エネルギースペ クトルの最良の評価值である近似解を求めるこ とをアンフォールディング若しくはアジャスト メントと呼び，いろいろな計算コードが開発さ

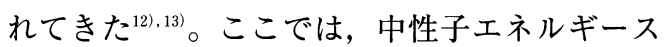
ペクトルのアジャストメントに SAND - II コー ド12)を使用した。 


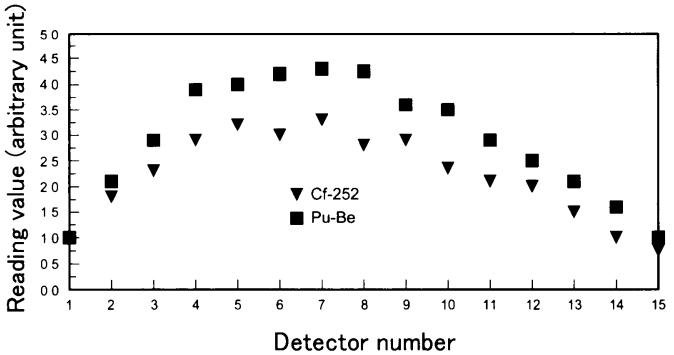

Fig. 3 Relative reading values measured with the neutron dosimeter for bare ${ }^{252} \mathrm{Cf}$ and bare $\mathrm{Pu}-\mathrm{Be}$ neutron sources.

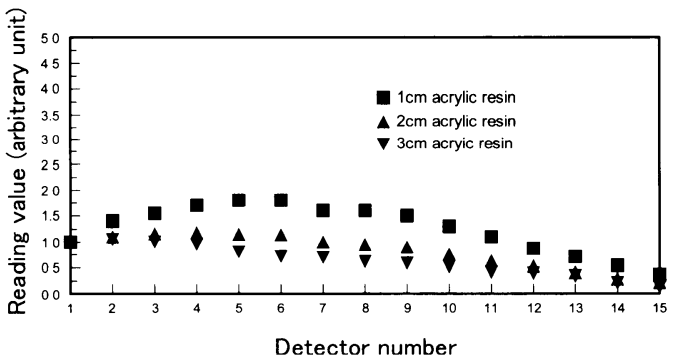

Fig. 4 Relative reading values measured with the neutron dosimeter for $\mathrm{Pu}-\mathrm{Be}$ neutron source shielded by $1 \mathrm{~cm}, 2 \mathrm{~cm}$ and $3 \mathrm{~cm}$ acrylic resins.

\section{5. 結果及び考察}

$5 \cdot 1$ 中性子スペクトロメータの基礎特性

Fig. 3 に， ${ }^{252} \mathrm{Cf}$ 並びに $\mathrm{Pu}-\mathrm{Be}$ 中性子源を用 いた中性子場で得られた中性子線量計の中心軸 に沿った読み取り值分布を示す。また，Fig. 4 に, $\mathrm{Pu}-\mathrm{Be}$ 中性子源と中性子線量計の間に厚 さ $1 \mathrm{~cm}, 2 \mathrm{~cm}, 3 \mathrm{~cm}$ のアクリル樹脂を挿入し た中性子場で, Fig. 5 に, $\mathrm{Pu}-\mathrm{Be}$ 中性子源と中 性子線量計の間に厚さ $5 \mathrm{~cm}$ の鉛, 厚さ $5 \mathrm{~cm}$ のパラフィン, 厚さ $10 \mathrm{~cm}$ の黒鉛を挿入した 中性子場で得られた中性子線量計の中心軸に沿 つた読み取り值分布を示す。ここで, 各位置で の読み取り値は, 中性子線量計の第 1 番目の素 子の読み取り值に規格化した。

いろいろな中性子場における中性子線量計の 応答測定結果から, ${ }^{60} \mathrm{Co}$ の $\gamma$ 線に等価な中性

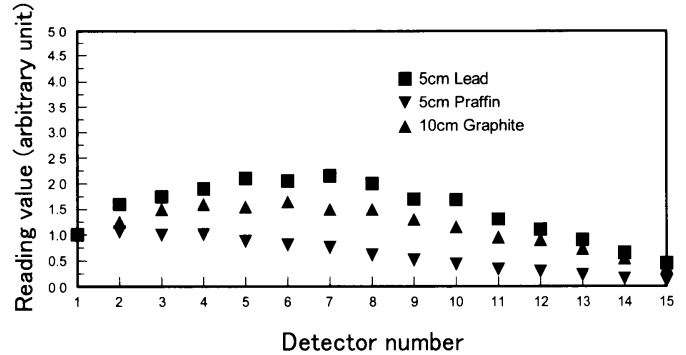

Fig. 5 Relative reading values measured with the neutron dosimeter for $\mathrm{Pu}-\mathrm{Be}$ neutron source shielded by $5 \mathrm{~cm}$ lead, $5 \mathrm{~cm}$ paraffin and $10 \mathrm{~cm}$ graphite.

子線量の中心軸に沿った読み取り值分布が，中 性子エネルギースペクトルの相違並びに中性子 線量情報をあらわしていることがわかる。すな わち，今回作製した中性子線量計を用いた中性 子エネルギースペクトル測定並びに中性子線量 評価が可能であることが確認された。

\section{$5 \cdot 2$ 応答関数及び応答行列}

中性子線量計の最大読み取り值に規格化した モンテカルロ計算による応答関数と照射実験で 得られた中心軸に沿った読み取り值の深部分布 比較を Fig. 6, Fig. 7 に示す。これらはそれぞ れ ${ }^{252} \mathrm{Cf}$ 中性子源からの中性子, $\mathrm{Pu}-\mathrm{Be}$ 中性子 源からの中性子に対する結果を示している。計 算結果には統計誤差に伴う誤差が 2 〜 程度 含まれ，実験結果には，熱蛍光量の測定のばら つきに起因する誤差が $5 \%$ 程度含まれると考 えられる。また，モンテカルロ計算におい て， ${ }^{252} \mathrm{Cf}$ 中性子源からの入射中性子エネルギー は， MCNP の入力として， ${ }^{252} \mathrm{Cf}$ 核分裂中性子 エネルギースペクトルを用いたが， $\mathrm{Pu}-\mathrm{Be}$ 中 性子源からの入射中性子エネルギーは，3.2 $\mathrm{MeV}$ の平均中性子エネルギーを用いて行った。

Fig. 6, 7 より, 中性子線量計の深部におい て，若干の相違が認められるが，計算結果と実 験結果が良く一致しているのがわかる。深部で の反応率分布において見られる相違は，実験体 系と計算体系の差に起因するものである。すな 


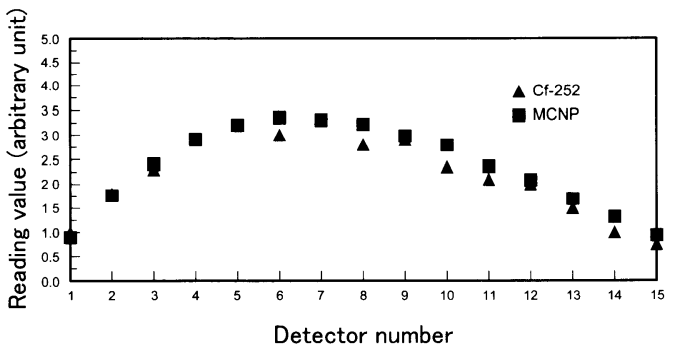

Fig. 6 Comparison between relative reading values measured with the neutron dosimeter and response function calculated with $\mathrm{MCNP}$ in the case of ${ }^{252} \mathrm{Cf}$ neutron source.

わち, 実験においては, 中性子源から発生した 中性子が周囲の建造物で散乱され，ょり低いエ ネルギーの中性子となって中性子線量計に入射 しているのに対して, 計算においては, 中性子 線量計の周囲は真空として取り扱い, 中性子源 から発生した中性子のみが中性子線量計に入射 しているためである。このことは，中性子源と 中性子線量計の周囲をコンクリートで取り囲ん だ計算結果から確認した。以上のように，中性 子線量計の中性子に対する応答関数の計算結果 と実験結果が誤差の範囲内で一致していること から，上記と同様の方法で $10^{-9} \mathrm{MeV}$ から 20 $\mathrm{MeV}$ の中性子に対する応答関数を決定した。 更に，計算により得られた応答関数を使用して

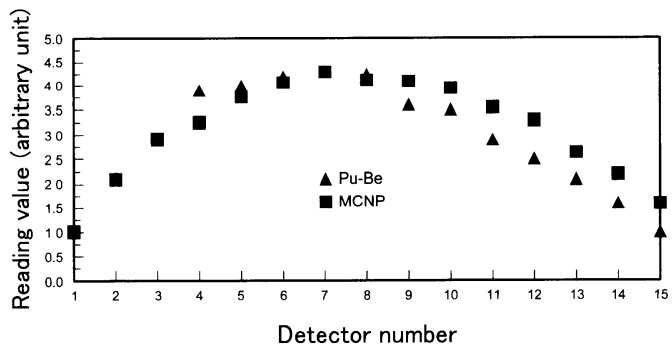

Fig. 7 Comparison between relative reading values measured with the neutron dosimeter and response function calculated with MCNP in the case of $\mathrm{Pu}-\mathrm{Be}$ neutron source.

中性子のエネルギー分布を評価するための応答 行列を作成した。応答行列を Fig. 8 に示す。

\section{$5 \cdot 3$ 中性子エネルギースペクトル}

Fig. 8 に示された中性子線量計のモンテカル 口計算による応答行列と照射実験で得られ た ${ }^{60} \mathrm{Co} の \gamma$ 線に等価な中性子線量の読み取り 值の深部分布から, $1 / E$ 中性子エネルギース ペクトルを初期值として SAND - II コードでア ジャストメントした ${ }^{252} \mathrm{Cf}$ と $\mathrm{Pu}-\mathrm{Be}$ 中性子源か らの中性子に対する中性子エネルギースペクト ルを Fig. 9 に示す。

一般に, 中性子減速にもとづくいろいろな検 出器を組み合わせた中性子スペクトロメータは,

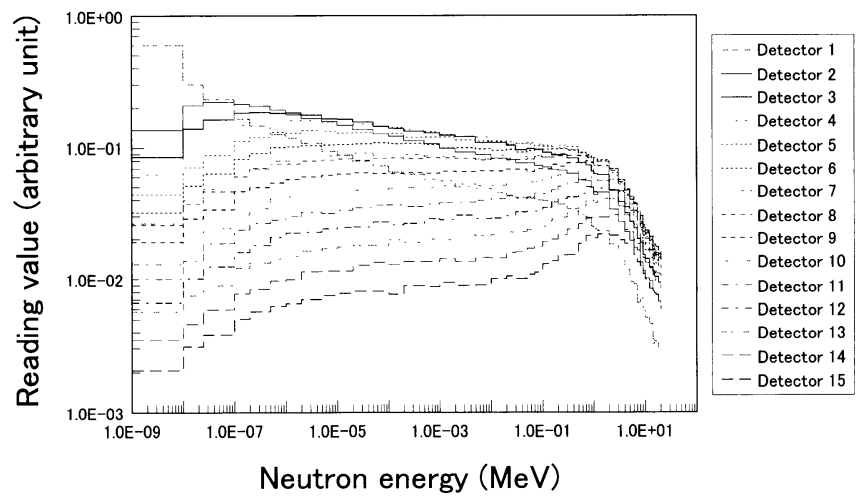

Fig. 8 Response matrix of the neutron dosimeter from $10^{-9} \mathrm{MeV}$ to $20 \mathrm{MeV}$ calculated with MCNP. 


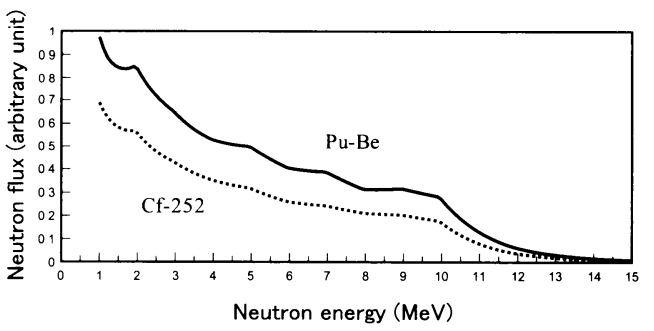

Fig. 9 Neutron energy spectra adjusted and measured with the neutron dosimeter in the case of ${ }^{252} \mathrm{Cf}$ and $\mathrm{Pu}-\mathrm{Be}$ neutron sources.

入射中性子のエネルギー分布に関する情報を簡 単に得ることが可能であるが, エネルギー分解 能が悪いという欠点を持っている。しかし， Fig. 9 からわかるように, ${ }^{252} \mathrm{Cf}$ 中性子源の場合 のアジャストメントされた中性子エネルギース

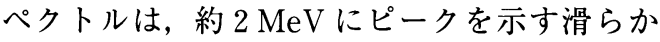
な変化を示している。一方, $\mathrm{Pu}-\mathrm{Be}$ 中性子源 の場合, 明確では無いが, $2 \mathrm{MeV}$ 近傍, $5 \mathrm{MeV}$ 近傍, $7 \mathrm{MeV}$ 近傍にピークのある中性子エネ ルギースペクトルを示している。このことは, 読み取り值からアジャストメントするための初 期值として, 両中性子源とも $1 / E$ 中性子エネ ルギースペクトルを用いたにもかかわらず,

Fig. 2 に示した ${ }^{252} \mathrm{Cf}$ と $\mathrm{Pu}-\mathrm{Be}$ 中性子源の中性 子エネルギースペクトルと定性的に良く一致し ている。

以上の結果より, 今回作製した簢易パッシブ 中性子線量計の応答行列並びに中性子エネルギ ースペクトルのアジャストメント法の精度が確 認された。

\section{$5 \cdot 4$ 中性子線量評価}

ここでは，今回作製した中性子線量計を用い た中性子線量評価法について検討し, 評価され た中性子線量結果, 並びにその精度について考 察する。

中性子線量計の照射実験で得られた ${ }^{60} \mathrm{Co} の \gamma$ 線に等価な中性子線量の読み取り值から, SANDーIIードを用いてアジャストメントさ

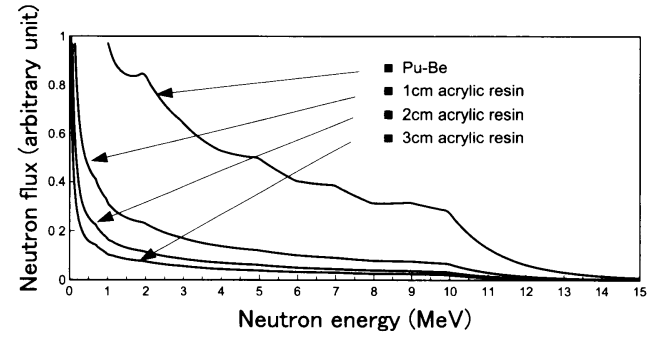

Fig. 10 Neutron energy spectra adjusted and measured with the neutron dosimeter for neutron field II, III, IV and V.

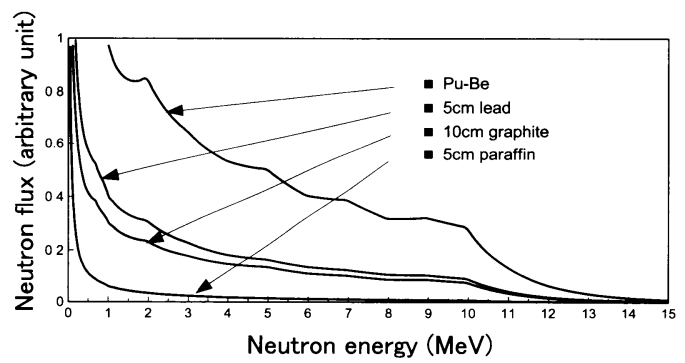

Fig. 11 Neutron energy spectra adjusted and measured with the neutron dosimeter for neutron field II, VI, VII and VII.

れた中性子エネルギースペクトルを Fig. 10， Fig. 11 に示す。

更に，アジャストメントされた中性子エネル ギースペクトルに ICRP Pub. 74 の換算係数を 乗じ，エネルギーにわたって積分することによ り中性子線量を評価した。ここでは，換算係数 として, ICRU 球及びスラブにいろいろなジオ メトリーで入射する単一エネルギー中性子に対 する，単位中性子フルエンスあたりの周辺線量 当量 $H^{*}(10) / \Phi （$ 単位 $\mathrm{pSv} \mathrm{cm}{ }^{2}$ ）を使用した。 いろいろな中性子場において，シーベルトメ ータで測定された中性子線量率 $(\mathrm{mSv} / \mathrm{hr})$ と 今回作製した中性子線量計で測定・評価された 中性子線量率 $(\mathrm{mGy} / \mathrm{hr})$ の比較を Table 2 に 示す。ここで，熱蛍光読取装置は ${ }^{60} \mathrm{Co} \gamma$ 線で 校正されているため，中性子線量計で測定・評 価した中性子線量率は， ${ }^{60} \mathrm{Co} \gamma$ 線に等価な吸収 線量率である。Table 2 からわかるように，今 
Table 2 Comparison of neutron doses measured and evaluated with the neutron dosimeter and Sievert meter (rem counter)

\begin{tabular}{cccc}
\hline \multirow{2}{*}{ Neutron field } & \multicolumn{2}{c}{ Neutron dose rate } & $\begin{array}{c}\text { Neutron dose response } \\
\text { (Gy/SV) }\end{array}$ \\
\cline { 2 - 4 } & $\begin{array}{c}\text { Present method } \\
(\mathrm{mGy} / \mathrm{hr})^{*}\end{array}$ & $\begin{array}{c}\text { Sievert meter } \\
(\mathrm{mSV} / \mathrm{hr})\end{array}$ & - \\
I & - & - & $1.06 \mathrm{E}-04$ \\
II & $8.52 \mathrm{E}-05$ & 0.8 & $1.26 \mathrm{E}-04$ \\
III & $9.46 \mathrm{E}-05$ & 0.75 & $1.39 \mathrm{E}-04$ \\
IV & $9.72 \mathrm{E}-05$ & 0.7 & $1.12 \mathrm{E}-04$ \\
V & $7.31 \mathrm{E}-05$ & 0.65 & $1.22 \mathrm{E}-04$ \\
VI & $9.12 \mathrm{E}-05$ & 0.75 & $1.45 \mathrm{E}-04$ \\
VII & $5.21 \mathrm{E}-05$ & 0.51 & $1.33 \mathrm{E}-04$ \\
VIII & $7.39 \mathrm{E}-05$ & 0.39 & \\
\hline${ }^{60}$ & &
\end{tabular}

回作製した中性子線量計の中性子線量応答は, いろいろな中性子場においても $1.06 \times 10^{-4}$ か ら $1.45 \times 10^{-4} \mathrm{~Gy} / \mathrm{Sv}$ すなわち平均 $1.26 \times 10^{-4}$ $\mathrm{Gy} / \mathrm{Sv}$ と中性子場の違いにかかわらずシーべ ルトメータと相対標準偏差 12\% 以内で，ほぼ 一定である。このことは, 熱蛍光素子とアクリ ル樹脂減速材を組み合わせた簡易パッシブ中性 子線量計とその応答行列を用いた中性子線量測 定評価法が，いろいろな放射線場における熱中 性子から数 $\mathrm{MeV}$ の範囲の中性子エネルギーに 対する平常時中性子モニタリングのための有効 な方法であることを示唆している。

一般に, ICRP Pub. 74 に述べられている中 性子線量換算係数のエネルギー依存性により, 中性子線量は, 中性子エネルギースペクトルに 大きく依存する。すなわち, 同じ全中性子強度 を持っ中性子場であったとしても，中性子エネ ルギースペクトルが異なれば，異なった中性子 線量を与える。そこで, 中性子線量を精度良く 評価するためには，ただ単に全中性子強度を測 定するのではなく, 中性子エネルギースペクト ルについての情報を, 最終的には, 中性子エネ ルギースペクトルを測定・評価しなければなら ないことが強調される。

\section{6. まとめ}

本研究から以下のことが結論として得られた。 1. 熱蛍光素子とアクリル樹脂隇速材を組み合
わせることにより, 簡便なパッシブ中性子 線量計を作製した。

2. その中性子線量計の $10^{-9} \mathrm{MeV}$ から 20 $\mathrm{MeV}$ までの単色エネルギー中性子に対す る応答行列を MCNP モンテカルロコード を用いて作成した。

3. その作成した応答行列と SAND - II コード を用いることにより，中性子線量計の読み 取り值から中性子エネルギースペクトルを 推定することができた。

4. 推定された中性子エネルギースペクトルに もとづき評価された ${ }^{60} \mathrm{Co} の \gamma$ 線に等価な 中性子線量は, シーベルトメータとほぼ同 じ中性子線量応答を示した。

5. 今回作製した簡易パッシブ中性子線量計は, いろいろな中性子場における平常時中性子 モニタリングのための有用な測定器である。

\section{文献}

1) Gayton, F. M., Harvey, J. R. and Jackson, J. H., Thermoluminescence and its application in reactor environments, J. Br. Nucl. Energy Soc., 11, 125140 (1972)

2) Piltingsrud, H. V. and Engelke, M. J., A Passive Broad-Energy-Response Neutron SpectrometerDosimeter, Neutron Monitoring for Radiaton Protection Purposes (Vienna: IAEA), STI/PUB /718, Vol. 1, pp.123-138 (1973)

3) Singh, D., Burgkhardt, B. and Piesch, E., A pas- 
sive neutron spectrometer and dosimeter using LiF : Mg, Ti thermoluminescent detectors, $\mathrm{Nucl}$. Instrum. Methods, 142, 409-415(1977)

4) Turner, T. W., Fews, A. P. and Henshaw, D. L., A CR-39 neutron spectrometer of sensitivity 1 mrem in the energy range $100 \mathrm{keV}-20 \mathrm{MeV}$ with personal dosimetry applications, Nucl. Tracks, 8, 341-344(1984)

5) Fews, A. P., Portwood, T., Henshaw, D. L., Turner, T. W., Worley, A., Schraube, H., Burger, G. and Booz, J., CR-39 Neutron Spectrometer with Application in $10 \mu \mathrm{Sv}$ Dosimetry, Proc. 5th Symp. on Neutron Dosimetry, Radiation. Protection Aspect, Vol. 1, pp.479-488(1985)

6) Apt, K. E. and Schiager, K. J., A passive environmental neutron dosimeter, Health Phys., 28, 474476(1975)

7) Uwamino, Y., Nakamura, T. and Hara, A., Two types of multi-moderator neutron spectrometers: Gamma-ray insensitive type and high-effi- ciency type, Nucl. Instrum. Methods, 239, 299-309 (1985)

8) Honda, Y., Ogawa, Y. and Kimura, Y., A simple passive neutron spectrum indicator using $\mathrm{CaSO}_{4}$ : Tm thermoluminescent detectors, Radiat. Prot. Dosim., 34, 229-232(1990)

9) Profio, A. E., Radiation Shielding and Dosimetry, pp.23-27, John Wiley \& Sons, New York (1979)

10) Briesmeister, J. F., MCNP-A General Monte Carlo N-Particle Transport Code Version4B, LA12625-M (1997)

11）日本アイソトープ協会訳, ICRP Publication 74, 外部放射線に対する放射線防護に用いるための 換算係数, pp.221-222, 丸善, 東京 (1999)

12) Griffin, P. J., Kelly, J. and VanDenburg, J. W., User's Manual for SNL-SAND-II Code, SAND933957 (1994)

13) Rust, B. W., Ingersoll, D. T. and Burrus, W. R., A User's Manual for the FERDO and FERD Unfolding Codes, ORNL/TM-8720 (1983) 


\title{
Abstract
}

\section{Development of Simple Passive Neutron Dosimeter with Cylindrical Acrylic Resin Moderator Using Thermoluminescent Detector}

\author{
Yoshihiro Ogawa and Takafumi Senoo \\ Department of Informatics, School of Science and Engineering, Kinki University \\ 3-4-1 Kowakae, Higashi-Osaka-shi, Osaka 577-8502, Japan
}

\begin{abstract}
In comparison with direct readings of neutron dose rate by Sievert meter, a passive thermal neutron detector inserted into moderator shows possibilities of not only intermediate and fast neutron measurement but also accumulated dose measurement during long term monitoring periods in low level neutron dose rate. Here, simple passive neutron dosimeter (10 cm diameter and $15 \mathrm{~cm}$ length) consisting of stratified acrylic resin disc $(10 \mathrm{~cm}$ diameter and $0.5 \mathrm{~cm}$ thickness $)$ which inserted a pair of the thermoluminescent elements, $\mathrm{CaSO}_{4}: \mathrm{Tm}+{ }^{6} \mathrm{LiF}$ and $\mathrm{CaSO}_{4}: \mathrm{Tm}+{ }^{7} \mathrm{LiF}$, as a thermal neutron detector, was produced. Performance and features of the neutron dosimeter were examined in various moderating neutron fields of ${ }^{252} \mathrm{Cf}$ and $\mathrm{Pu}-\mathrm{Be}$ neutron sources. In addition, the response function of neutron dosimeter from $10^{-9} \mathrm{MeV}$ to $20 \mathrm{MeV}$ was made and neutron energy spectrum was estimated with adjustment method using the reading values of neutron dosimeter. Finally, accuracy on neutron dose evaluation method and applicability of the neutron dosimeter to neutron monitoring were investigated

The neutron energy spectra that were adjusted with the response function and the reading values of neutron dosimeter were reproduced for those of ${ }^{252} \mathrm{Cf}$ and $\mathrm{Pu}-\mathrm{Be}$ neutron sources at a good accuracy. The neutron doses evaluated based on estimated neutron energy spectra showed the neutron dose response indicating from $1.06 \times 10^{-4}$ to $1.45 \times 10^{-4} \mathrm{~Gy} / \mathrm{Sv}$, and $(1.26 \pm 0.14) \times 10^{-4} \mathrm{~Gy} / \mathrm{Sv}$ on an average according to various moderating neutron fields, which was almost equal to the Sievert meter. From the results obtained, the present simple passive neutron dosimeter was found to be a useful neutron detector for routine neutron monitoring for the range of neutron energy from several $\mathrm{MeV}$ to thermal energy in various radiation fields.
\end{abstract}

(Received March 8, 2005) 